UDC 542.61

DOI https://doi.org/10.32838/2663-5941/2020.2-2/10

Cheltonov M.M.

Ukrainian State University of Chemical Technology

Kirichenko A.L.

State Enterprise Research-Industrial Complex "Pavlograd Chemical Plant"

Ustimenko E.B.

State Enterprise Research-Industrial Complex "Pavlograd Chemical Plant"

\title{
EXTRACTION OF CYCLOTETRAMETHYLENETETRANITRAMINE FROM SOLID PROPELLANT UTILIZATION PRODUCTS
}

The purpose of this work is to assess the ability of dimethyl sulphoxide for extraction of cyclotetramethylene tetranitramine (nitramine) from solid propellant polymer crumb of different sizes under laboratory conditions. Currently, for Ukraine, the disposal of ammunition, warheads, solid propellant rocket engines (solid propellant rockets) with expired storage is relevant. To solve this problem, the specialists of the "Pavlograd Chemical Plant" have been solving the problems of safe disposal of solid propellant using the hydromechanical method for more than 15 years. The hydromechanical method consists in the hydrodynamic extraction of fragments of solid propellant with its with its subsequent shredding.

Nitramine was extracted with dimethyl sulphoxide from the obtained SP polymer crumb followed by extract separation from the refined polymer crumb and nitramine deposition by adding the diluent (water) which does not dissolve nitramine into the extract solution. At the preliminary stage of work a water-soluble constituent - ammonium perchlorate was extracted from SP polymer crumb and because it is soluble both in dimethyl sulphoxide and in water, its presence in dimethyl sulphoxide extract is undesirable, since in case of dimethyl sulphoxide regeneration it is associated with additional costs. It was determined that the use of dimethyl sulphoxide makes it possible to extract about $87.6 \%$ of nitramine from SP polymer crumb with average particle size of up to $2 \mathrm{~mm}$. According to the obtained thermochemical calculations and experimental work with the formulations of emulsion explosives with the addition of refined polymer matrix (PM) of various contents, it shows that the addition of PM to the composition of emulsion explosives to $10 \%$ leads to an increase in $11 \%$ of the energy characteristics of emulsion explosives, but does not lead to the formation of an additional volume of toxic gases, the amount of which remains virtually unchanged. The selected formulation with the optimal content of refined PM in emulsion explosives, which is recommended for use in experimental conditions. As the main pilot industrial method for the extraction of nitramine from SP, a method using dimethyl sulphoxide after a detailed technical and economic analysis is recommended.

Key words: solid propellant, extraction, cyclotetramethylenetetranitramine, dimethyl sulphoxide.

Introduction. Currently, for Ukraine, the disposal of ammunition, warheads, solid propellant rocket engines (solid propellant rockets) with expired storage is relevant. To solve this problem, the specialists of the "Pavlograd Chemical Plant" have been solving the problems of safe disposal of solid propellant using the hydromechanical method for more than 15 years. The hydromechanical method consists in the hydrodynamic extraction of fragments of solid propellant with its with its subsequent shredding.

Solid propellant (SP) is a polybutadiene-based polymer binder, filled with an oxidizer (ammonium perchlorate), as well as energetic additives (nitramine, i.e. cyclotetramethylenetetranitramine and aluminium) and process additives.
In the course of LMCs hydromechanical disposal the operating medium is a water, which extracts the most of water-soluble oxidizer (ammonium perchlorate) during extraction and shredding of solid propellant.

Nitramine may be extracted from the derived polymer crumb of solid propellant by selective organic solvents [1,3] either by separation of extract from raffinate (refined oil) with a subsequent nitramine deposition using the addition of a diluent (such as water) to the solution, or separation of nitramines and SP polymer crumb due to different densities of these components [2] in solution with intermediate density.

According to the literature [3], dimethyl sulphoxide (DMSO), N-methylpyrrolidone and $\gamma$-butyrolactone 
have the highest solvent ability to nitramine, but for selective extraction of nitramine from polybutadiene-based solid propellant, DMSO is the most promising of the above solvents [1], since it has the highest solvent ability to nitramine among the above solvents, it is more affordable and is lower in cost than the above mentioned organic solvents.

Statement of the main research material. The purpose of this work is a study of the ability of DMSO extraction nitramine from SP polymer crumb of different sizes, i.e. "fine" fraction (average particle size is up to $2 \times 2 \times 2 \mathrm{~mm}$ ) and "coarse" fraction (average particle size is from $7 \times 4 \times 4 \mathrm{~mm}$ to $15 \times 4 \times 4 \mathrm{~mm}$ ). The polymer crumb of solid propellant contains, in addition to nitramine, the amount of ammonium perchlorate, which remains in SP upon extracting from LMC and shredding. And at the stage of nitramine extraction it is a by-product, since it is soluble both in dimethyl sulphoxide and in water, therefore its subsequent extraction from the spent aqueous solutions involves additional costs.

At the preliminary stage of laboratory studies the ammonium perchlorate was extracted with water from SP polymer crumb at temperature $75-80{ }^{\circ} \mathrm{C}$ for 2 hours. Then the derived solid polymer matrix (PM) was filtered, dried, weighed and analyzed for content of ammonium perchlorate, nitramine, aluminium and moisture. Table 1 shows chemical composition of PM "coarse" and "fine" fractions before and after water extraction respectively.

Procedure for laboratory studies for evaluation of DMSO extraction ability to extract nitramine from polymer matrix consisted of the following: PM and DMSO were weighed and placed into the beaker at the ratio of $1: 2.5$ respectively, then they were mixed by stirring mechanism (rate of stirring $-400 \mathrm{rpm}$ ) for $2 \mathrm{~h}$ at a temperature of $20-80{ }^{\circ} \mathrm{C}$. Resulting PM refined suspension was filtered through the folded paper filter, dried and weighed. The water (diluent) was added while stirring to nitramine-containing DMSO extract at the room temperature (DMSO : water ratio $-1: 1)$. Then after nitramine precipitation, the derived precipitate was filtered through the folded paper filter, dried and weighed. It was determined the sensitivity of obtained nitramine to mechanical effects (impact, friction) as well as thermal stability by means of the differential thermal analysis (DTA) using Linseis L81 differential thermal analyzer. In order to determine safety characteristics the refined polymer matrix was tested for sensitivity to mechanical effects (impact, friction) and sensitivity to detonation pulse after nitramine extraction. The spent DMSO aqueous solution was regenerated by vacuum distillation in Laborota 4003 rotary evaporator under the following conditions: evaporating flask rotation speed of 50-75 rpm, residual pressure of $11 \mathrm{~mm} \mathrm{Hg}$, maximum temperature of $100{ }^{\circ} \mathrm{C}$.

Results and discussion. Based on the results of the studies, temperature dependences of the degree of nitramine extraction from PM are presented, which are shown in Fig. 1: a) from the "fine" PM fraction, b) from the "coarse" PM fraction.

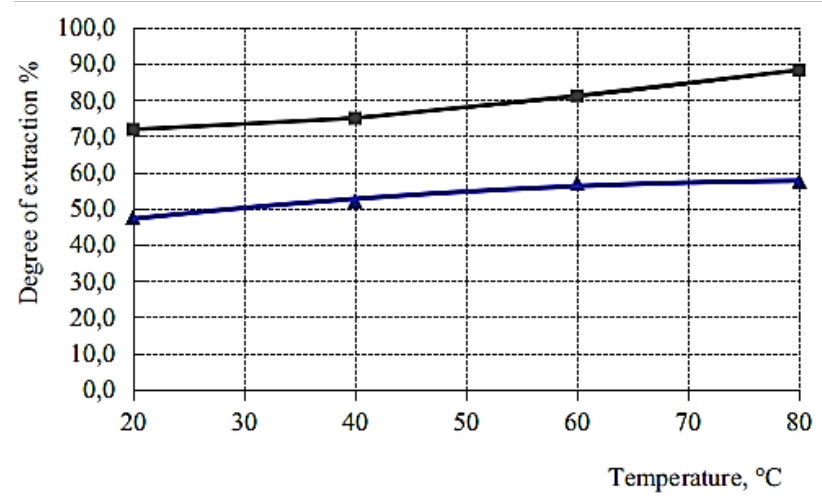

Fig. 1. The temperature dependence of the degree of extraction of nitramine: a) from a "fine" PM fraction, b) from a "coarse" PM fraction (stirrer rotation speed $400 \mathrm{rpm}$, extraction process time $2 \mathrm{~h}$ )

From the presented in fig. 1 dependences it follows that with increasing temperature the degree of extraction of nitramine from PM "fine" and "coarse" fractions increases according to the polynomial dependencies, which are described by the approxi-

Table 1

Chemical composition of PM coarse and fine fractions before and after water extraction

\begin{tabular}{|c|c|c|c|c|}
\hline Component & \multicolumn{2}{|c|}{$\begin{array}{c}\text { Mass content of components of "fine" } \\
\text { fraction, \% }\end{array}$} & $\begin{array}{c}\text { Mass content of components of "coarse" } \\
\text { fraction, \% }\end{array}$ \\
\hline & $\begin{array}{c}\text { Before } \\
\text { extraction }\end{array}$ & After extraction & $\begin{array}{c}\text { Before } \\
\text { extraction }\end{array}$ & After extraction \\
\hline Polymer binder & 9 & 13.1 & 7.8 & 8.3 \\
\hline Ammonium perchlorate & 47 & 16.4 & 28.0 & 16.1 \\
\hline Nitramine & 25 & 34.5 & 30.4 & 34.4 \\
\hline Aluminium & 19 & 31.4 & 26.9 & 25.1 \\
\hline Moisture & - & 4.6 & 6.9 & 16.7 \\
\hline
\end{tabular}


mating equation with the value of the reliability of the approximation $\mathrm{R}^{2} \geq 0.99$ :

$$
\eta=a t^{2}+b t+c
$$

where: $\eta$ is the degree of extraction of nitramine, $\%$; $\mathrm{t}$ is the temperature, ${ }^{\circ} \mathrm{C} ; \mathrm{a}, \mathrm{b}, \mathrm{c}-$ empirical coefficients depending on the temperature of extraction from: "fine" PM fraction $(\mathrm{a}=0.0021, \mathrm{~b}=0.0555, \mathrm{c}=69.7)$, "coarse" PM fraction $(\mathrm{a}=-0.0031, \mathrm{~b}=0.4995$, $\mathrm{c}=48.2$ ).

According to fig. 1, the optimal temperature for the extraction of nitramine from PM under specified conditions is a temperature range of $60-80^{\circ} \mathrm{C}$, the degree of extraction of a "fine" fraction from a PM is $81.1-87.6 \%$, the degree of extraction of a "coarse" fraction from a PM is $66.8-68.2 \%$.

Fig. 2 shows the appearance of nitramine crystals under the microscope Leica DMILM upon extraction of DMSO from PM ("fine" fraction).

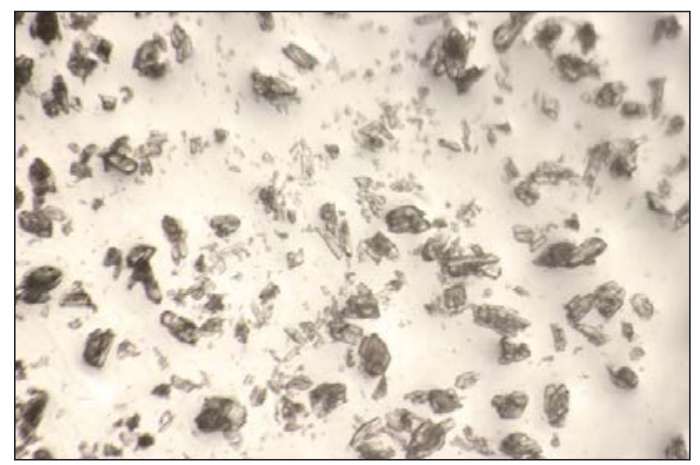

Fig. 2. Picture of nitramine crystals upon extraction of DMSO from PM ("fine" fraction)
As we can see at the picture (Fig. 2), the tests resulted in crystals which had halfway formed faces and defects and which required modification for further reuse.

In order to evaluate safety parameters in handling the derived product, its sensitivity to mechanical effects was determined. Impact and friction sensitivities were measured using BAM Hammer 782-0000 and BAM Friction Apparatus 781-0000 respectively according to the methods [4]. It was evaluated that refined nitramine had an impact sensitivity of $4 \ldots 10 \mathrm{~J}$ and friction sensitivity of $216 \mathrm{~N}$ to $>360 \mathrm{~N}$. The obtained data show that the impact and friction sensitivity limit of derived nitramine is 2 and 2.7 times higher than minimum requirement values $\geq 2 \mathrm{~J}$ and $\geq 80 \mathrm{~N}$ respectively, which were established by UN requirements to ensure safety during transportation [4].

To evaluate the chemical purity of the obtained nitramine the DTAmethod was used. When conducting DTA tests, the heating rate of nitramine was $10^{\circ} \mathrm{C} / \mathrm{min}$. The DTA thermogram of the obtained nitramine is shown in Fig. 3. Fig. 4 shows the DTA thermogram of commercial nitramine for comparison.

Based on the results of comparative analysis of DTA thermograms, it has been determined that nitramine obtained due to extraction from SP using dimethyl sulfoxide (Fig.3) has similar thermophysical characteristics to a commercial product.

During SP conversion reprocessing after extraction of nitramine wastes like DMSO aqueous solution and refined PM which are subject to additional reprocessing or disposal were formed. Table 2 shows amount of wastes for reprocessing of $100 \mathrm{~g}$ of PM using the example of fine fraction.

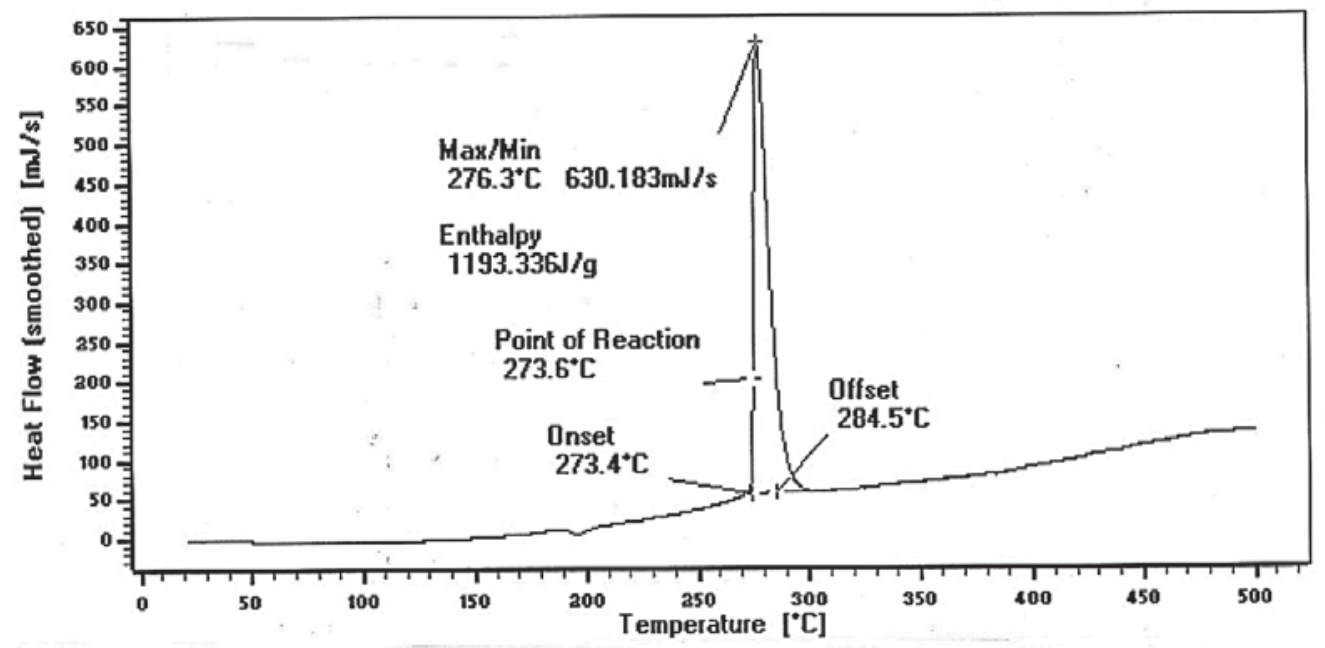

Fig. 3. DTA thermogram for nitramine obtained 
Amount of wastes from SP conversion reprocessing

\begin{tabular}{|c|c|}
\hline Waste description & $\begin{array}{c}\text { Amount of wastes } \\
\text { for reprocessing } \\
\text { of } \mathbf{1 0 0} \mathbf{g} \text { of PM, } \mathbf{~}\end{array}$ \\
\hline DMSO aqueous solution & 464.3 \\
\hline Refined PM & 76.5 \\
\hline
\end{tabular}

The spent DMSO aqueous solution was regenerated by vacuum distillation in a rotary evaporator Laborota 4003 resulting in separation of the mixture into primary components suitable for reuse.

To select a method of disposal of refined PM, containing in its composition nitramine of up to $34.5 \%$, ammonium perchlorate of up to $16.4 \%$ and not less than $4.6 \%$ of moisture, characteristics of its sensitivity to mechanical stress were determined. According to the results of the studies performed, it was established that the sensitivity to impact and friction is $>50$ $\mathrm{J}$ and $>360 \mathrm{~N}$, respectively. Thus, it was determined that the sensitivity to mechanical impact of refined PM with respect to PM prior to nitramine extraction decreased to impact from $32 \mathrm{~J}$ to $>50 \mathrm{~J}$, to friction from $220 \mathrm{~N}$ to $>360 \mathrm{~N}$. It should be noted that refined PM has sufficient energy calorific potential and therefore it is of interest to use it in industrial explosives composition as an energy additive.

Taking into account the current trends in the development of industrial explosives, it is obvious that the most secure basis for processing refined PM is water-filled emulsion explosives, which are a het- erogeneous system consisting of a classical inverse emulsion (Division 5.1) and technological additives. This is primarily due to low sensitivity of emulsion explosives to mechanical and electrostatic effects, as well as characteristic properties of emulsion to create a relatively safe, phlegmatizing environment when it is filled with energetic materials, such as nitramine, aluminum. In addition, flexibility of emulsion explosives formulation ensures not only manufacturability and safety of its manufacture, but balanced oxygen balance $\left(\mathrm{O}_{\mathrm{b}}\right)$, which in turn minimizes formation of toxic gases $\left(\mathrm{CO}, \mathrm{NO}_{\mathrm{x}}\right)$ during explosion.

To assess the effect of content of refined PM included into emulsion explosive on its physico-chemical characteristics, thermochemical calculations were performed for model formulations of emulsion explosives [5-6] containing from $0 \%$ to $15 \%$ of refined PM. Table 3 shows the results of thermochemical calculations.

According to Table 3, with up to $10 \%$ increase in content of refined PM in composition of emulsion explosives, heat of explosion increases by $11 \%$. At the same time, content of $\mathrm{CO}$ in composition of explosion products slightly increases and remains at a minimum level (up to $3.83 \%$ ). With further up to $15 \%$ increase in content of refined PM in composition of emulsion explosives, heat of explosion remains almost unchanged, but this significantly increases concentration of $\mathrm{CO}$ in composition of explosion products to $11.67 \%$.

To assess the influence of the PM content in the explosive composition on its explosive characteristics,

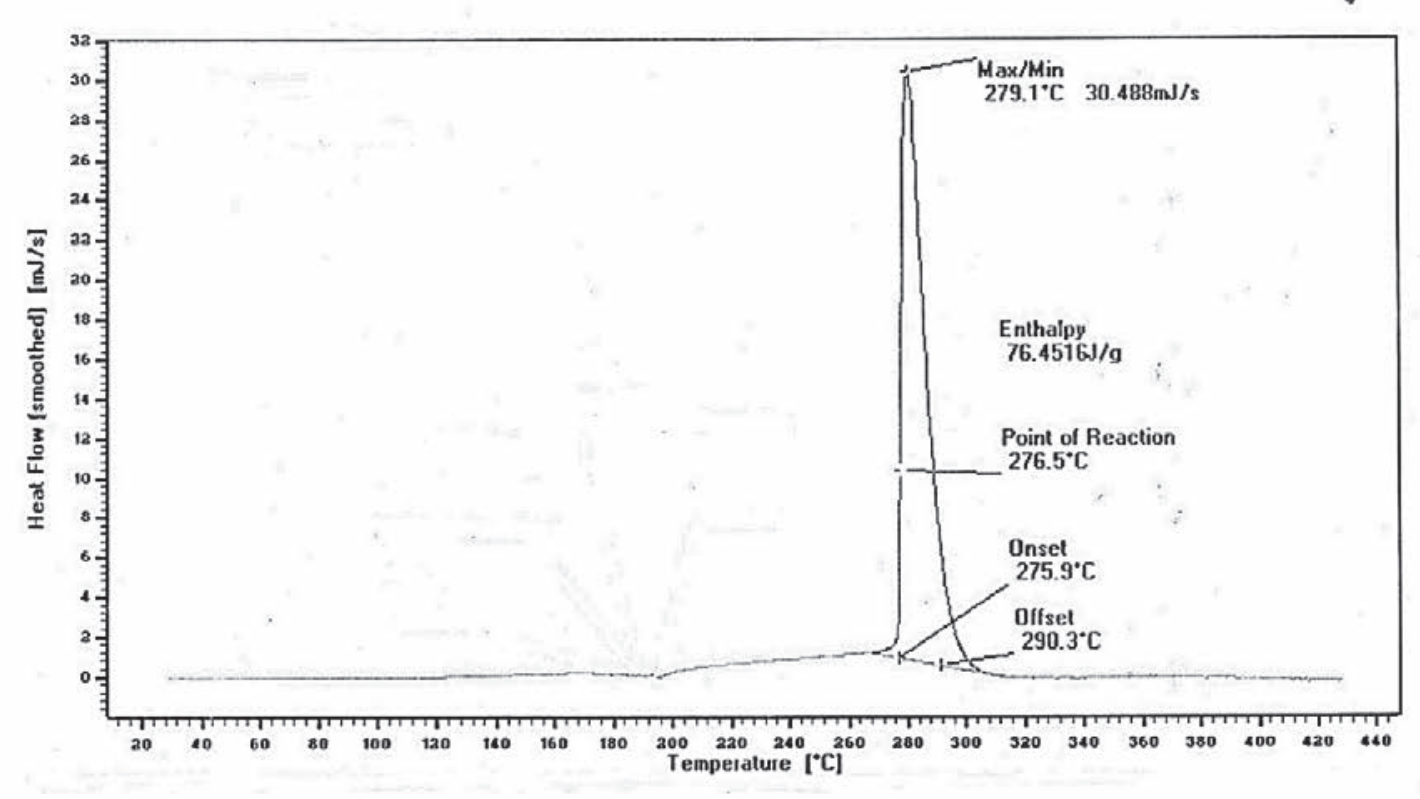

Fig. 4. DTA thermogram for commercial nitramine 
we studied the propagation velocity of the detonation wave in the explosive charges in a polyethylene shell with a diameter of $90 \mathrm{~mm}$ and a length of $600 \mathrm{~mm}$. The charges were initiated from an intermediate detonator (TNT) weighing 200 g. An "Explometr" device was used to determine the detonation velocity of explosive charges. The principle of operation, which is based on measuring the transit time of the luminous front of the detonation wave on a fixed segment of the charge. The results of the measurements are presented as the ratio of the distance and travel time of the detonation wave in the charge of the emulsion explosives and are presented in table 4. Also in table 4 presents the parameters of the density of explosive charges and the completeness of detonation.

Data analysis table. 4 shows that upon the initiation of emulsion explosives with a density of $1080 \div 1200 \mathrm{~kg} / \mathrm{m}^{3}$ and a PM content of up to $10 \%$ in the charge, a stationary detonation wave propagates at a detonation speed from $4115.7 \mathrm{~m} / \mathrm{s}$ to $4171.1 \mathrm{~m} / \mathrm{s}$.
With an increase in the PM content to $15 \%$ in the charge of emulsion explosives, a decrease in the detonation speed to $3450.6 \mathrm{~m} / \mathrm{s}$ is observed. In this case, the decrease in the detonation speed is due to the incompleteness of the explosive transformation reaction occurring behind the detonation wave front. Thus, the above theoretical and experimental studies show that the optimal PM content in the composition of emulsion explosives should not exceed $10 \%$.

After a detailed technical and economic analysis and comparison of this method with alternative methods of extracting nitramine from products of SP disposal, it can be considered as the main experimental-industrial method for nitramine extraction.

After its modification nitramine obtained can be reused in compositions of heat-resistant explosives, solid rocket propellant, and non-electric initiation systems.

Regeneration of spent DMSO aqueous solution and use of refined PM as a filler in compositions of

Table 3

Results of thermochemical calculations for emulsion explosives containing refined PM

\begin{tabular}{|c|c|c|c|c|c|c|}
\hline \multirow{2}{*}{ Parameter } & \multicolumn{6}{|c|}{ Parameter value depending on refined PM content } \\
\hline & $0 \%$ & $2.5 \%$ & $5 \%$ & $\mathbf{7 . 5 \%}$ & $10 \%$ & $15 \%$ \\
\hline \multicolumn{7}{|c|}{ Composition of emulsion explosive, $\%$} \\
\hline Oxidizing phase & 69.2 & 70.4 & 59.8 & 58.1 & 56.1 & 51.4 \\
\hline Fuel phase & 6.8 & 6.1 & 5.2 & 4.4 & 3.9 & 3.6 \\
\hline Ammonium nitrate & 24.0 & 21.0 & 30.0 & 30.0 & 30.0 & 30 \\
\hline $\mathrm{PM}$ & 0 & 2.5 & 5.0 & 7.5 & 10.0 & 15 \\
\hline \multicolumn{7}{|c|}{ Thermochemical parameters } \\
\hline Explosion heat, $\mathrm{kJ} / \mathrm{kg}$ & 767 & 787 & 802.5 & 842 & 865 & 853 \\
\hline Gas volume, 1 & 878.5 & 865 & 851.4 & 857 & 855 & 867 \\
\hline Oxygen balance & -0.29 & -0.42 & -0.59 & -0.94 & -1.5 & -6 \\
\hline Explosion temperature, $\mathrm{K}$ & 2701 & 2778 & 2856 & 2955 & 3033 & 3055 \\
\hline \multicolumn{7}{|c|}{ Composition of explosion products, $\%$} \\
\hline $\mathrm{CO}$ & 1.92 & 2.13 & 2.44 & 2.89 & 3.83 & 11.67 \\
\hline $\mathrm{CO}_{2}$ & 12.66 & 11.95 & 11.12 & 10.54 & 9.22 & 0 \\
\hline $\mathrm{H}_{2} \mathrm{O}$ & 48.73 & 48.24 & 47.75 & 47.55 & 47.29 & 47.47 \\
\hline $\mathrm{N}_{2}$ & 24.11 & 23.44 & 22.7 & 23.64 & 23.72 & 22.94 \\
\hline $\mathrm{Al}_{2} \mathrm{O}_{3}$ & 0 & 1.42 & 2.83 & 4.25 & 5.67 & 8.5 \\
\hline $\mathrm{CaCl}_{2}$ & 1.05 & 1.25 & 1.45 & 1.46 & 1.56 & 1.85 \\
\hline $\mathrm{CaCO}_{3}$ & 11.52 & 11.56 & 10.68 & 9.67 & 8.71 & 7.53 \\
\hline
\end{tabular}

Table 4

The results of experimental studies to determine the thermochemical parameters of emulsion explosives based on PM

\begin{tabular}{|c|c|c|c|c|c|c|}
\hline \multirow{2}{*}{ Parameter } & \multicolumn{7}{|c|}{ The content of refined PM in emulsion explosives } \\
\cline { 2 - 7 } & $\mathbf{0 \%}$ & $\mathbf{2 . 5 \%}$ & $\mathbf{5 \%}$ & $\mathbf{7 . 5 \%}$ & $\mathbf{1 0 \%}$ & $\mathbf{1 5 \%}$ \\
\hline \multicolumn{7}{|c|}{ Thermochemical parameters } \\
\hline Density, $\mathrm{kg} / \mathrm{m}^{3}$ & 1120.0 & 1080.0 & 1090.0 & 1100.0 & 1120.0 & 1095.0 \\
\hline \multirow{2}{*}{ Detonation completeness } & $\begin{array}{c}\text { Full } \\
\text { detonation }\end{array}$ & $\begin{array}{c}\text { Full } \\
\text { detonation }\end{array}$ & $\begin{array}{c}\text { Full } \\
\text { detonation }\end{array}$ & $\begin{array}{c}\text { Full } \\
\text { detonation }\end{array}$ & $\begin{array}{c}\text { Full } \\
\text { detonation }\end{array}$ & $\begin{array}{c}\text { Full } \\
\text { detonation }\end{array}$ \\
\hline Detonation speed, $\mathrm{m} / \mathrm{s}$ & 4171.1 & 4115.7 & 4132.9 & 4147.9 & 4171.1 & 3450.6 \\
\hline
\end{tabular}


emulsion explosives will allow creating an economically and environmentally grounded closed cycle of the process of extracting nitramine from solid rocket propellant disposal products.

Conclusions. As a result of the studies, the dependences of the influence of temperature on the degree of extraction of nitramine obtained from the PM of the "fine" and "coarse" fractions using DMSO are obtained, which are described by the general approximating equation with an approximation confidence value of $R^{2} \geq 0.99$.

It was found that the highest degree of extraction $87.6 \%$ of nitramine from the PM of the "fine" fraction was achieved in the experiment, which was carried out for 2 hours, at a temperature of $80^{\circ} \mathrm{C}$, and a rotation speed of the mechanical stirrer of $400 \mathrm{rpm}$.

The degree of extraction nitramine during extraction of dimethyl sulfoxide from PM of "coarse" fraction was $68.2 \%$, which is 1.3 times less than the result obtained in the previous experiment. Thus, it is more preferable to perform extraction from "fine" fraction of PM using dimethyl sulfoxide.

Refined PM has less than the minimum acceptable UN sensitivity requirements: to detonation impulse, mechanical stress, and indicates that refined PM is not dangerous for transportation as cargo and can be recommended for use as a filler in compositions of emulsion explosives after additional phlegmatization with reverse type emulsion.

On the basis of thermochemical calculations and experimental studies with the formulations of emulsion explosives with the addition of refined PM of various contents, it shows that the addition of refined $\mathrm{PM}$ in the composition of emulsion explosives up to $10 \%$ leads to an increase in $11 \%$ of the energy characteristics of emulsion explosives, but it does not lead to formation of an additional volume of toxic gases, the amount of which remains practically unchanged. This formulation is recommended for practical tryout under test conditions.

\section{References:}

1. Основы промышленной технологии утилизации крупногабаритных твёрдотопливных зарядов / Забелин Л.В., Р.В. Гафиятулин, А.Н. Поник, В.Ю. Мелешко. Москва : ООО «Недра-Бизнесцентр», 2004. 226 с.

2. Патент 2145588 России, МПК С 06 В 21/00, F 42 D 5/04. Способ экологически чистой регенерации нитраминов из смесевых твёрдых ракетных топлив / В.Ю. Мелешко, Г.В. Кирий, В.А. Карелин, С.А. Гусев, В.И. Гребенкин, Ю.М. Милехин, Ю.С. Соломонов, А.Н. Ключников (Россия). - № 98109125/02; Заявл.05.05.1998; Опубл. 20.02.2000. 9 с.

3. Ломовцева Г.А., Веселова Е.В., Збарский В.Л., Юдин Н.В. О некоторых особенностях растворимости циклических нитраминов в органических растворителях. Успехи в химии и химической технологии: сб. научных трудов, РХТУ им. Д. И. Менделеева. Москва, 2012. Т. XXVI, № 3 (132). С. 21-25.

4. Recommendations on the transport of dangerous goods, manual of tests and criteria. 5th revised ed. New York and Geneva, 2009. 456 p.

5. Афанасенков А.Н., Богомолов В.М., Воскобойников И.М. Расчёт параметров детонационной волны смесей взрывчатых веществ с инертными добавками. Физика горения и взрыва. 1970. Т. 6, № 2. С. 182-186.

6. Физика взрыва / под ред. Л.П. Орленко. в 2-х т. Т. 1. Москва : Физматлит, 2002. 826 с.

\section{Челтонов М.М., Кириченко О.Л., Устименко Є.Б. ЕКСТРАГУВАННЯ ЦИКЛОТЕТРАМЕТИЛЕНТЕТРАНІТРАМІНУ 3 ПРОДУКТІВ УТИЛІЗАЦЇ̈ ТВЕРДОГО РАКЕТНОГО ПАЛИВА}

На сьогодні в ході утилізачії твердих ракетних палив (ТРП) із закінченим терміном зберігання зі споряджених корпусів двигунів (СКД) актуальним $\epsilon$ питання повернення матеріальних ресурсів, а саме ефективного вилучення компонентів ТРП (амонію перхлорату, ииклотетраметилентетранітраміну). Об'єктом досліджень є тип ТРП, який представляє собою полімерне зв'язуче на основі полібутадієну, наповнене окислювачем (амонієм перхлоратом), енергетичними (циклотетраметилентетранітрамін, алюмінієм) $i$ технологічними домішками. Одним із способів вилучення ичклотетраметилентетранітраміну (нітраміну) з ТРП є застосування селективних органічних розчинників, якими є диметилсульфоксид (ДМСО), N-метилпіролідон, ү-бутіролактон.

Метою иієєї роботи є оцінка екстракційної здатності диметилсульфоксиду (ДМСО) для вилучення нітраміну з полімерної крихти твердого ракетного палива різного розміру в лабораторних умовах. 3 отриманої полімерної крихти ТРП нитрамін екстрагувався ДМСО з подальшим відділенням екстракту від рафінованої полімерної крихти і висадженням нитраміну шляхом введення в розчин екстракту розчинника, нерозчинюючого його - води. На попередньому етапі робіт з полімерної крихти ТРП було вилучено водорозчинний компонент - амоній перхлорат, який розчиняється як в ДМСО, так і у воді і тому його присутність в екстракті ДМСО небажана, оскільки процес регенерації ДМСО 
ускладнюється додатковими витратами. Визначено, щчо застосування ДМСО дозволяє вилучати з полімерної крихти ТРП з середнім розміром часток до 2 мм до 87,6\% нітраміну. Проведений термохімічний розрахунок рецептури емульсійної вибухової речовини з рафінованою крихтою ТРП після вилучення нітраміну різного змісту. Згідно з отриманими термохімічними розрахунками вибрана рецептура з оптимальним змістом рафінованої полімерної матриці в емульсійній вибуховій речовині, яку рекомендується використати в промислових умовах. В якості основного дослідно-промислового методу вилучення нітраміну з ТРП рекомендується метод із застосуванням ДМСО після детального техніко-економічного аналізу.

Ключові слова: тверде ракетне паливо, екстракція, цииклотетраметилентетранітрамін, диметилсульфоксид. 